University of Nebraska - Lincoln

DigitalCommons@University of Nebraska - Lincoln

Faculty Publications in Educational

Administration

Educational Administration, Department of

2020

Institutional Responses to Events Challenging Campus Climates:

Examining the Power in Language

Crystal Garcia

Benjamin Arnberg

Jessica Weise

Marit Winborn

Follow this and additional works at: https://digitalcommons.unl.edu/cehsedadfacpub

Part of the Higher Education Administration Commons

This Article is brought to you for free and open access by the Educational Administration, Department of at DigitalCommons@University of Nebraska - Lincoln. It has been accepted for inclusion in Faculty Publications in Educational Administration by an authorized administrator of DigitalCommons@University of Nebraska - Lincoln. 


\title{
Institutional Responses to Events Challenging Campus Climates: Examining the Power in Language
}

\author{
Crystal E. Garcia, Benjamin Arnberg, \\ Jessica Weise, and Marit Winborn
}

Department of Educational Foundations, Leadership, and Technology, Auburn University

Marit Winborn is now at the Department of Development Services, Texas Christian University.

Correspondence - Crystal E. Garcia; current address: Department of Educational Administration, University of Nebraska-Lincoln; crystal.garcia@unl.edu

\begin{abstract}
This qualitative study explored administrative responses to local and sociopolitical events challenging campus climates at public research universities. Using critical discourse analysis, we examined the use of language as a form of power in publicly available documents addressing campus climate for diversity and inclusion at 31 U.S. institutions. Findings center 3 themes: underlying power in determining what to address; the power of language in perpetuating or deconstructing power, privilege, and oppression; and the distinction between espousing and enacting commitments to diversity, equity, and inclusion. Implications for research and practice are discussed.
\end{abstract}

Keywords: campus climates, college administrators, critical discourse analysis, institutional responses, public research universities

Published in Journal of Diversity in Higher Education, Vol. 13, No. 4 (2020), pp 345-354 doi:10.1037/dheoooo130

Copyright (c) 2019 National Association of Diversity Officers in Higher Education; published by American Psychological Association. Used by permission. "This paper is not the copy of record and may not exactly replicate the authoritative document published in the APA journal."

Submitted January 17, 2019; revised May 20, 2019; accepted May 29, 2019; published July $1,2019$. 
Tigher education can foster activism, creative thinking, and so1 cial change. Yet literature on campus climates show that higher education institutions are not always inclusive and welcoming to all students (Hurtado \& Ponjuan, 2005; Locks, Hurtado, Bowman, \& Oseguera, 2008; Nuñez, 2009). Campus climates are "the current perceptions, attitudes, and expectations that define the institution and its members" (Hurtado, Clayton-Pedersen, Allen, \& Milem, 1999, p. iii), whereas campus climate for racial and ethnic diversity are "linked with a historical legacy of exclusion at the institution, its structural diversity, and behaviors on campus that include interactions inside and outside the classroom" (p. iii). Notably, the historical exclusion Hurtado et al. (1999) described is not limited to racial and ethnic diversity, but also extends to other marginalized identities. As Smith (2009) described,

When an individual's identities align significantly with the cultural identity of an institution, there is usually a sense of comfort and a lack of awareness of certain salient features of institutional culture ... the alignment between an individual or group and the institution can translate into definitions of excellence that reward some groups and not others. (p. 27)

In this view, campus climate disproportionately affects visibility, belonging, and access to excellence for particular student groups. A campus climate is created and enforced through policy, administrative practice, and pedagogy; these can enhance or detract from equity to the extent that these enable universal excellence or render only certain identities visible and embraced (Hurtado, Alvarez, GuillermoWann, Cuellar, \& Arellano, 2012).

Campus climate issues are difficult to address in any sociopolitical context; these are even more difficult in a time of persistent national hostility to diversity commitments. Institutions of higher learning have long lived within the cultural imagination as beacons of moral leadership and social progress. This privileged position means that institutions' responses to both locally based and sociopolitical issues that challenge campus climates affect a sense of inclusion for diverse students and a public perception of how best to address these crises outside academe. As Freire expressed, "the educator has the duty of 
not being neutral" (Horton \& Freire, 1990, p. 180). We must continue to dissect the intersection of language, campus climate, and institutional power so that we may better understand ways we can deconstruct systemic inequities and construct equitable educational environments (Ladson-Billings, 1998). The importance of institutional response was exemplified at the University of Missouri, where students organized as a result of the lack of response from upper administration regarding racial tensions on campus and society leading to a student hunger strike and the football team refusing to practice and compete (Izadi, 2015). Events at the University of Missouri showed us that while particular incidents can affect ways that students experience campus environments, what is perhaps equally or even more important are institutional responses that reflect a commitment to diversity and inclusion.

Given ways that sociopolitical and local incidents have challenged campus climates, it is imperative that we examine how institutional administrators publicly respond to such incidents as they may affect how students experience campus environments and the extent to which they feel as though they are accepted and belong within those environments (Strayhorn, 2012). This study will contribute to this conversation by examining the following research questions:

1. In what ways (if any) does language used in institutional responses to events that affect campus climates for diversity support notions of inclusivity and equity?

2. In what ways (if any) does language used in institutional responses to events that affect campus climates for diversity perpetuate inequitable and oppressive ideologies?

\section{Literature Review}

\section{Discourse in Educational Contexts}

Policies, whether national or local, have implications for how higher education institutions address diversity and issues that affect diverse student groups. Literature emphasizes the role and power of discourse in shaping the reality and understanding of diversity (Alvesson 
\& Kärreman, 2011; Chang, 2002; Hardy \& Woodcock, 2015; Hoffman \& Mitchell, 2016; Iverson, 2007, 2012; Wooffitt, 2005). Alvesson and Kärreman (2011) reflected on microdiscourse or "little d discourse" and macrodiscourse or "big D" discourse as counter balancing concepts in organizational discourse analysis. Contextual factors such as language, social norms, and institutional setting and discourse need to be considered in discourse analysis because of the interconnected nature of discourse and context (Alvesson \& Kärreman, 2011).

Researchers have examined the importance of discourse in various educational contexts. For instance, Chang (2002) analyzed legal decisions related to diversity initiatives that affect higher education campuses, specifically affirmative action. Through this analysis, Chang (2002) argued that diversity on college campuses serves more than a political or ideological agenda. Viewing diversity as transformative discourse as opposed to discourse of preservation has implications for student learning and the democratization of institutions (Chang, 2002). Discourse of preservation "focuses almost exclusively on only those interests and initiatives associated with admitting underrepresented students of color" (Chang, 2002, p. 130) whereas transformative discourse focuses on the educational benefits associated with diversity (Chang, 2002). Hardy and Woodcock (2015) demonstrated how policies across Western countries (Canada, England, Australia, and the United States) reflected the effects of neoliberal conditions and argued that discourse needs to be analyzed to understand the historical lineage of problematic policies and their implications on difference and diversity.

Many higher education institutions implement a diversity policy or diversity action plan to show their commitment to diversity and inclusion. Iverson (2007) conducted a study of such discursive practices in diversity action plans at $\mathbf{2 1}$ land-grant institutions. Through critical policy discourse analysis and Critical Race Theory, this study showed that diversity action plans were centered on whiteness. This in turn standardized whiteness, or White, male, middle-class culture. Discourse in the diversity action plans also labeled Students of Color as "at risk," reinforcing deficit thinking (Iverson, 2007). Additional themes that emerged from Iverson's (2007) study included marketplace discourse in which Students of Color were viewed as a commodity, and discourse of democracy where Students of Color were viewed 
as a tool to reach democracy (Iverson, 2007). In a replicated study, Iverson (2012) focused more broadly on "the unquestioned assumptions, structures, and practices that construct diversity" (p. 152). Diversity plans represented a "discourse of access," othering the diverse individual as "excluded," "underrepresented," "marginalized," "unwelcome," "not well represented," and "hardly noticeable" (Iverson, 2012, p. 166).

\section{Institutional Responses to Campus Climate Issues}

Campus climate tensions are not new to higher education institutions; researchers have focused on these issues for some time (Hurtado, Milem, Clayton-Pedersen, \& Allen, 1998). However, the development of technology in recent years, primarily by way of social media, have both contributed to the ways students experience the climate as well as the extent that these issues are visible to the public (Tynes, Rose, \& Markoe, 2013). Upper level administrators often release information publicly in the form of an e-mail or news article when the university is targeted by sudden negative publicity (Cole \& Harper, 2017), yet limited literature exists on these institutional responses to issues that challenge campus climate.

Some studies have examined institutional responses to campus climate issues. For instance Cole and Harper (2017) examined responses to campus racial incidents from 18 college presidents. Their findings showed that presidents' responses fell into three categories: those that did not mention the incident at all within the statement (3), those that included a discussion of the incident broadly while avoiding the specifics (11), and those that provided a full description of the incident (4). Findings also distinguished among responses that addressed the perpetrators of the incidents (13) and those targeted and found that fewer presidents identified the targets of racialized incidents on campus (5), while all statements addressed the greater campus community. These findings point to trends among institutional responses in responding to racial incidents in broad, often vague ways.

Davis and Harris (2016) used Critical Race Theory to examine how institutional leaders responded to three racial incidents that occurred on different college campuses. Findings pointed to three main issues: "(a) lack of action-oriented language, (b) overreliance upon remorse 
and regret, and (c) failure to claim responsibility" (p. 72). Notably within these findings the authors discussed the difficulty institutions seemed to face in articulating the nature of the actions as racist. Based on these findings the authors asserted that upper level administrators must not only apologize for the incident that happened on their campus, but collaborate with organizations and students on campus to deliver policies and action steps on how the university is going to combat against these issues and create a more inclusive campus.

In a study on administrative responses to student activism, Hoffman and Mitchell (2016) found that administrative responses placed responsibility and labor on the students to establish equity on campus. This action eliminates power differentials between students and administrators by placing unpaid labor on the students to create more equitable spaces on campus. At the same time, the language used in the administrators' responses reinforce the power dynamic between students and administrators by not aligning their language regarding a commitment to diversity to action. Specifically, "responses demonstrate how the institution deploys nonperformative language to assert ill-defined commitments to minoritized populations, center whiteness and other majority cultures, and devalue students and their contributions to the campus environments" (Hoffman \& Mitchell, 2016, p. 283).

\section{Theoretical Framework}

We adopted a critical theoretical approach to examine ways that institutions publicly respond to incidents challenging campus climates. Critical research examines ways that power, oppression, and privilege shape society and, as a result, how human life is affected by "systems of inequity such as classism, racism, and sexism" (Lather, 1992, p. 87). Therefore, rather than "merely describe social reality," critical researchers strive to dig deeper and "raise critical consciousness" (Carspecken, 2012, p. 44). Criticalists examine power dynamics among "groups and individuals within a society-identifying who gains and who loses in specific situations" (Kincheloe \& McLaren, 2002, p. 288).

A particularly salient component of critical theory in relation to this study is the power of language, which denotes and constructs the world (Kincheloe \& McLaren, 2002). We focused on ways that 
language was used in institutional responses while considering discursive practices, which are "defined as a set of tacit rules that regulate what can and cannot be said; who can speak with the blessings of authority and who must listen; and whose social constructions are valid and whose are erroneous and unimportant" (Kincheloe \& McLaren, 2002, p. 94). Our aim in using a critical framework was to deconstruct language used by institutional administrators, focusing on ways these messages recognized and silenced certain realities.

\section{Methodology}

We used qualitative, critical discourse analysis (CDA) to explore ways that language in institutional responses to events that affect campus climates at public research universities either supports inclusivity and equity or perpetuates inequitable and oppressive ideologies. CDA studies the use of language with the notion that "language is performative; that is, it is always doing something with consequence (whether intended or not)" (Lester, Lochmiller, \& Gabriel, 2016, p. 3). According to Blommaert and Bulcaen (2000) CDA recognizes "discourse is an opaque power object in modern societies and CDA aims to make it more visible and transparent" (p. 448). We used several approaches to ensure the trustworthiness of our research including collecting rich data (Glesne, 2010) and triangulation (Denzin, 1978). Triangulation was attended to by including multiple researchers in this study. As a team we were able to review one another's work in data collection and engage in discussions around analysis.

\section{Data Collection}

We narrowed our institutional focus to public research universities in the United States to ensure "representativeness or typicality of the settings" (Maxwell, 2013). We used a purposeful selection process (Maxwell, 2013) to select the particular institutions by first selecting four states within each of the four U.S. Census (2015) regions-West, Midwest, Northeast, South-totaling 16 states in an effort to balance our national representation. Using a map of the 2016 presidential election electoral college votes (Associated Press, 2017), we then selected an 
equal number of states within each region that voted Democratic and Republican to account for the influence of the political climate. We realized this was an imperfect measure of political climate, however we wanted to obtain some measure of political diversity within the contexts our institutions were situated in. We then selected two public research institutions categorized as R1 "very high research activity" (Indiana University Center for Postsecondary Research, n.d.) or R2 "high research activity" if there were not two R1 institutions in the state. One state had only one public research university, which brought our total to 31 institutions ranging in enrollment size from just under 16 , ooo students to over 65,000 students. Notably, the University of Nebraska-Lincoln and the University of Nebraska-Omaha are the only two public research universities in the state. We have listed both here in our study, however because they are led by the same president and chancellor the documents collected for these campuses were the same.

Each of the four members of our research team was assigned seven or eight institutions to conduct an initial rigorous review of institutional websites as well as other online sources, such as news outlets, for publicly available responses from upper-level institutional administrators (i.e., presidents, chancellors, provosts, etc.) pertaining to incidents affecting campus climate as well as those that connected to the greater societal climate between November, 2016 and August, 2018. We chose not to include statements from chief diversity officers or other administrators associated with offices of diversity and inclusion because climate responses are often relegated to these offices and we were interested in how other campus leaders responded to these issues. We used the 2016 presidential election and the time of data collection as bookmarkers for our focus. Once the initial researcher completed their review, a second research team member re-reviewed the files collected and online sources for any missed documents in an effort to ensure the trustworthiness of our data collection.

In addition to direct statements we also collected news stories and press releases that provided contextual understanding of issues occurring on campus. This process resulted in a total of just under 420 documents, 303 of which were direct statements from institutional leaders. Table 1 provides a list of each institution included in our analysis alongside its state, region, and 2016 presidential election results in addition to the total number of documents collected and number of direct statements analyzed for each institution. 
Table 1. Institutional Characteristics and Data Collected

\begin{tabular}{|c|c|c|c|c|c|}
\hline Institution & State & Region & $\begin{array}{l}\text { Election } \\
(D, R)\end{array}$ & $\begin{array}{l}\text { Total } \\
\text { docs }\end{array}$ & $\begin{array}{c}\text { Direct } \\
\text { statements }\end{array}$ \\
\hline Arizona State University & AZ & West & $\mathrm{R}$ & 11 & 6 \\
\hline Bowling Green State University & $\mathrm{OH}$ & Midwest & $\mathrm{R}$ & 9 & 1 \\
\hline Colorado State University & $\mathrm{CO}$ & West & $\mathrm{D}$ & 22 & 20 \\
\hline Florida State University & FL & South & $\mathrm{R}$ & 10 & 6 \\
\hline Illinois State University & IL & Midwest & $\mathrm{D}$ & 7 & 4 \\
\hline Michigan State University & MI & Midwest & $\mathrm{R}$ & 13 & 7 \\
\hline Pennsylvania State University & $\mathrm{PA}$ & Northeast & $\mathrm{R}$ & 14 & 7 \\
\hline San Diego State University & $\mathrm{CA}$ & West & $\mathrm{D}$ & 6 & 6 \\
\hline Texas A\&M University & $\mathrm{TX}$ & South & $\mathrm{R}$ & 15 & 14 \\
\hline Texas Tech University & $\mathrm{TX}$ & South & $\mathrm{R}$ & 10 & 5 \\
\hline The Ohio State University & $\mathrm{OH}$ & Midwest & $\mathrm{R}$ & 13 & 8 \\
\hline The University of Tennessee, Knoxville & $\mathrm{TN}$ & South & $\mathrm{R}$ & 15 & 6 \\
\hline University at Albany & NY & Northeast & $\mathrm{D}$ & 10 & 3 \\
\hline University at Buffalo & NY & Northeast & $\mathrm{D}$ & 15 & 14 \\
\hline University of Arizona & AZ & West & $\mathrm{R}$ & 13 & 8 \\
\hline University of California, Berkeley & $\mathrm{CA}$ & West & $\mathrm{D}$ & 16 & 10 \\
\hline University of Colorado, Boulder & $\mathrm{CO}$ & West & $\mathrm{D}$ & 29 & 27 \\
\hline University of Connecticut & $\mathrm{CT}$ & Northeast & $\mathrm{D}$ & 16 & 14 \\
\hline University of Florida & FL & South & $\mathrm{R}$ & 21 & 10 \\
\hline University of Illinois at Urbana-Champaign & IL & Midwest & $\mathrm{D}$ & 11 & 4 \\
\hline University of Massachusetts Amherst & MA & Northeast & $\mathrm{D}$ & 21 & 20 \\
\hline University of Massachusetts Boston & MA & Northeast & $\mathrm{D}$ & 11 & 11 \\
\hline University of Memphis & $\mathrm{TN}$ & South & $\mathrm{R}$ & 15 & 11 \\
\hline University of Michigan & MI & Midwest & $\mathrm{R}$ & 11 & 11 \\
\hline $\begin{array}{l}\text { University of Nebraska-Lincoln \& } \\
\text { University of Nebraska at Omaha }\end{array}$ & $\mathrm{NE}$ & Midwest & $\mathrm{R}$ & 14 & 8 \\
\hline University of Pittsburgh & PA & Northeast & $\mathrm{R}$ & 6 & 3 \\
\hline University of Virginia & VA & South & $\mathrm{D}$ & 20 & 19 \\
\hline University of Washington & WA & West & $\mathrm{D}$ & 23 & 22 \\
\hline Virginia Commonwealth University & VA & South & $\mathrm{D}$ & 7 & 4 \\
\hline Washington State University & WA & West & $\mathrm{D}$ & 15 & 14 \\
\hline
\end{tabular}

\section{Data Analysis}

Given our use of a CDA approach, we centered our analysis on the use of language within institutional responses. As Bakhtin (1981) wrote,

There are no "neutral" words and forms-words and forms that can belong to "no one"; language has been completely taken over, shot through with intentions and accents ... language is not an abstract system of normative forms but rather a concrete heteroglot conception of the world. All 
words have the "taste" of a profession, a genre, a tendency, a party, a particular work, a particular person, a generation, an age group, the day and hour. (p. 293)

We remained cognizant of the intricacies of language and used CDA to evaluate ways that university statements rendered visible an affirmative climate. As we collected and reviewed institutional documents, we questioned the extent to which words were enough to affect campus climate, whether words were able to clearly articulate an equity orientation, and if words were inherently inclusive.

Data analysis began with first cycle coding (Saldaña, 2016) during the data collection process. As we collected response documents, we read each statement while evaluating the usage of language and questioning ways that words could affect campus climate, articulate an equity orientation, and espouse inclusivity (Bakhtin, 1981). During this initial collection and review of statements, researchers constructed preliminary jottings (Saldaña, 2016) and engaged in team discussions regarding initial impressions and themes that emerged. Once we completed data collection, we then collaboratively constructed a coding framework around the following questions: (a) Was the response connected to a campus or broader sociopolitical issue? (b) Did the statement articulate a broad or well-defined diversity/inclusion stance? (c) Was the statement proactive or reactive to issues or incidents? And (d) What was the source of the statement (president, provost, official university communications office, etc.)? We coded the first set of institutional documents together and discussed areas that were unclear and any questions that arose. The researchers then divided up the institutions and coded all direct statement documents. We then worked together to identify overarching themes that emerged from the coding process, revisiting our preliminary jottings and using axial coding to identify relationships among the themes to refine these succinctly (Saldaña, 2016).

\section{Findings}

Findings from this study underscore the power that exists in language and, accordingly, points to ways that language is used by campus 
leaders as a form of power when addressing campus climates for diversity and inclusion. It was clear that what administrators chose to address and the language they used to do so was perhaps equally as important as what they chose not to address and, as a result, whose voices, identities, and experiences were silenced. For example, when referring to Richard Spencer's appearances at universities across the United States, following his unite the right rally in Charlottesville, did universities refer to him as a "controversial speaker" or a "white Nationalist"? Did they obscure his ideological stance by referring to the National Policy Institute? Or did they call him by name? There is greater power in a university castigating "controversy" when the student body may learn specifically what makes the speaker controversial and why the university labels it "abhorrent."

Here we outline three themes that emerged from the findings: (a) underlying power in determining what to address; (b) the power of language in perpetuating or deconstructing power, privilege, and oppression; and (c) and the distinction between espousing and enacting commitments to diversity, equity, and inclusion.

\section{Underlying Power in Determining What to Address}

One of the most notable findings was the inconsistency among institutions in terms of transparency in communicating institutional stances on issues affecting campus climates. While some institutions had many statements publicly and readily accessible through their institution's website, others offered few, if any, that were easily located. Though perhaps seemingly insignificant, the presence or absence of statements pointed to the underlying power that institutional leaders wielded in determining what was "important" enough to address, or rather, what statements were appropriate to be made publicly available and, as a result, whose realities were silenced by these responses and whose were made visible. Notably, the majority of these responses addressed sociopolitical issues rather than campus-based incidents except for those that caught local or national media attention. While we can only speculate as to why this may have been the case, it is possible that institutions did not want the public to learn about negative incidents that occurred on campus whereas sociopolitical issues were already known to the public. 
Among the statements that were available directly from the institution as opposed to other news sources, there was a disproportionate focus on DACA and President Trump's Executive Order on Immigration and Refugees compared to other issues. We located statements on the Executive Order for all institutions and at least one DACA response for all institutions except for the University of Tennessee, Knoxville. Together, this pointed to a broad pattern of institutions obscuring forms of diversity beyond racial, ethnic, and national identity such as sexuality, gender, ability, and religious identities.

To illustrate this finding, consider institutional responses to the Executive Order on Immigration and Refugees. All institutions in this study offered a public response to the Order and all included a focus on nationality, asserting that the Executive Order was in contrast with their commitment to diversity and the benefits that international students bring to the educational setting. For instance, the University of Illinois' Chancellor and Interim Vice Chancellor for Academic Affairs and Provost released a statement asserting, "The marginalization of international faculty, students, staff, and visiting scholars diminishes us all. This we will not abide."

While all of these responses reaffirmed a commitment to a diverse student community based on racial/ethnic/national identity, a large majority of institutions did not mention religious identity in this response, which was notable given that the countries included in this Order were all Muslim-majority countries. Six institutions included a connection to religious identity broadly within their statement. For instance, the President and Executive Vice President and Provost of the University of Virginia released a joint statement asserting, "Our University continues to enunciate values that support the bedrock principles of individual freedom, including freedom of expression and freedom of religion." However, the statement did not specifically call attention to the focus on members of the Muslim community. Considering tensions surrounding the Muslim community in political rhetoric, one could reason this was a relatively safe way to address the issue as the institutional leaders did not have to worry about offending stakeholders that did not view the policy as religiously targeted.

Four institutional chancellors and presidents (University of California, Berkeley; University of Pittsburgh; University of California, San Diego; University of Michigan), took their positions a step further by 
signing on to a letter from institutional leaders from across the country that specifically identified this Order as targeting Muslim-majority nations. The letter asserted,

This action unfairly targets seven predominantly Muslim countries in a manner inconsistent with America's best principles and greatest traditions. We welcome outstanding Muslim students and scholars from the United States and abroad, including the many who come from the seven affected countries.

This letter exemplified how specificity in institutional responses served to recognize and/or endorse forms of power and oppression.

As previously discussed, institutional responses primarily focused on racial, ethnic, and national identity, however none of the publicly available responses from any of the institutions explicitly addressed Black Lives Matter in the title of the release or within the focus of the content. We located one institution, the University of Nebraska-Lincoln, whose statements from the President and Chancellor of the University in support of their football players' decision to kneel during the National Anthem were still publicly available. However, the phrase "Black Lives Matter" was not mentioned in either statement. Rather, they both focused on the importance of First Amendment Rights and freedom of speech. Though not explicitly, the statements alluded to the reasons why the players were kneeling. For instance, the Chancellor stated, "Our student-athletes have provided us an opportunity to examine our own behaviors, engage in productive dialogue and consider alternate views about important issues of our time" while the President noted,

Our nation is dealing with difficult issues today, as we have for virtually our entire history. Each of us will react differently. College campuses, as much as any space, must be places where robust, even uncomfortable, debate is welcomed and encouraged.

Given the connection of the BLM movement to campus protests, particularly by way of kneeling during the National Anthem during 
college football games, the lack of public attention to the BLM movement raises some interesting questions for consideration in terms of what institutions deem as "safe" to publicly address as opposed to what could risk political capital.

A prime example of this issue was in regard to publicly available responses to issues surrounding transgender students. Five of the institutions had at least one statement affirming their commitment to an inclusive environment for transgender students on campus readily accessible on their institutional website while the others did not. All of these statements were in response to changes in legislation that stood in opposition to gender equity. For instance, the University of Washington's Office of the President released a statement entitled “Transgender rights are human rights." In contrast, the University of Tennessee released statements over the last few years that stood in opposition to inclusive practices for transgender individuals. While some of these statements actually stemmed from time outside of the constraints of focus for this project (November 2016 to August 2018), we felt that it was important to address these in order to provide context for statements (or a lack thereof) today. In 2015, the Office for Diversity and Inclusion at UT released a statement to the campus community focused on how pronoun usage contributes to inclusivity. An article reported by Inside Higher Ed (Jaschik, 2015) highlighted the President of UT's response, which stood in opposition to the statement released by the Office for Diversity and Inclusion,

Despite the aggressive efforts by UT Knoxville to communicate the fact that the campus does not require the use of gender-neutral pronouns, I am deeply concerned about the attention this matter continues to receive and the harm it has had on the reputation of the University of Tennessee ... The social issues and practices raised by the Office for Diversity and Inclusion are appropriate ones for discussion on a university campus. However, it was not appropriate to do so in a manner that suggests it is the expectation that all on campus embrace these practices.

In response, the information was removed from the website and not long after, other equity oriented initiatives spurred the state to defund 
the Office of Diversity at UT in 2016. In February 2018, one of the University's alumni spearheaded an effort to raise \$3 million for an endowment to privately fund the University's Pride Center (Compton, 2018). The University's Chancellor at that time, Beverly Davenport, reportedly asked these alumni to lead the efforts and was present at a fundraising event they hosted which raised \$300,000 (Compton, 2018). However, we could not find any press releases from the institution on this initiative. Instead, we located a termination letter for Chancellor Davenport written by President DiPietro that was reported in its entirety (see Tamburin, 2018). Though the letter did not mention Chancellor Davenport's support for the fundraising efforts, the timing of her termination raised questions of whether her public support of these efforts was a factor.

\section{The Power of Language in Perpetuating or Deconstructing Power,} Privilege, and Oppression

Use of language also came into play in terms of how specifically administrators addressed incidents challenging campus climate, and as a result, the extent to which they contributed to deconstructing systemic power, privilege, and oppression. For instance, the President at Texas A\&M University released a statement against a speaker's presence on campus stating that the perspectives espoused by this individual were "abhorrent" and held "no place in civilized dialogue and conversation." Yet, the president never specified who the speaker was or named the focus of this message. If an individual were to read the statement without knowing the context, they would have no idea what views the president was denouncing.

In contrast, the Chancellor of the University of Massachusetts offered a very specific and critical response:

The horrific events that unfolded over the weekend at the University of Virginia and the surrounding community of Charlottesville make it abundantly clear that we are living in a time when bigotry, racism, anti-Semitism and hatred have found their way into our mainstream social discourse. White supremacist and neo-Nazi groups that were once relegated to the shadows now feel emboldened to spew their venomous, 
violent ideology out in the open and have proclaimed their intent to preach their vile message in communities across the country. We condemn the actions of these white supremacists and neo-Nazis and we reject the false equivalence that suggests there are 'many sides' to this sort of hate.

Beyond simply condemning the act of violence, this individual offered a critical perspective that gave name to forms of racism and oppression.

Other institutions also explicitly denounced the events that occurred in Charlottesville, such as the Chancellor at the University of Pittsburgh who stated, "It was especially unsettling that the shocking scenes of violence and bigotry did not occur in some faraway place. They occurred on a public university campus in a college town near the start of its academic year-a place and time much like where we find ourselves today." A statement from UC Berkeley noted, "I join with millions of others to condemn the reprehensible acts of the racist groups ..."

There were a number of other instances in which institutions gave name to the forms of discrimination that took place within the campus context as well as within the sociopolitical environment. Another example occurred in the days following the 2016 presidential election after a number of incidents took place at the University of Michigan. The University President described,

We saw a threatening message painted on the rock near our campus; a student walking near campus was threatened with being lighted on fire because she wore a hijab; another student left his apartment to go to class and found a swastika with a message telling him to go home.

The president expressed,

We hope all members of our community can agree that we must not stand silent while facing expressions of bigotry, discrimination or hate that have become part of our national political discourse ... We do not seek to suppress political speech or ongoing debate of key issues. Rather, we are asking 
everyone to reject hate and bigotry and to provide personal support for one another.

One tension that often stemmed from institutional responses was the extent to which administrators condemned particular acts versus defending them by asserting the institution's commitment to First Amendment rights. Take for instance the following statement made by Texas Tech University administration in response to "racially insensitive comments" on social media:

Texas Tech University does not condone the abhorrent speech and views expressed in the video. As an institution of higher learning, we are strongly committed to diversity and inclusion. We foster and promote the freedom of expression, but condemn the use of hateful and derogatory language. As American citizens, we value our protections under the First Amendment, even when we do not support the content of a message.

While the majority of this segment seemed to stand in opposition of racist rhetoric, the final sentence of this passage suggests that we should accept it in the spirit of the First Amendment.

This was in contrast to the approach the president of the University of Memphis used to address controversial speakers on campus. The president noted that having these individuals on campus was a matter of "state and university free speech and public access policies," however unlike some other similar institutional responses that argued this was a First Amendment right, the president went on to say "We will be exploring several things in the coming weeks-an understanding of when such public access becomes disruptive to our campus and learning community and the boundary between opinion and hate speech." The president suggested that this discussion be added to "one of our upcoming Critical Conversations," which also denoted a method of action to be taken in response to the issue. In a separate statement, the president reiterated their stance:

[T] here is a difference, though, between free speech and hate speech meant to demean and humiliate ... A vibrant university community embraces this reality. It does not seek to 
silence debate and discussion; rather, it encourages and nurtures it. Similarly, though, a vibrant university community does not tolerate racism, bigotry and hate speech meant to demean, humiliate and degrade.

While the president affirmed the importance of free speech, they also gave name to forms of hate speech, noting these had no place within the community.

\section{Espousing Versus Enacting Commitments to Diversity, Equity, and Inclusion}

Oftentimes institutional responses articulated the university's stance on the situation or issue, yet they did not always coincide with stated actions that would occur in response. Many statements referred students to particular resources on campus such as the following from the Vice President of Student Affairs at the University of Florida:

Over the last few weeks, I've received a lot of questions from students. Many deal with what to do when faced with social injustices, controversial speakers or hate messages. These are valid questions, and it is important to recognize that messages of hate affect us all differently ... I encourage all of you to take care of yourselves and to find a safe outlet to express your emotions.

Not only did this response blur the bounds of diversity and issues that particular students face, but also defaulted to referring students to resources as opposed to action.

Rather than overly focus on which statements were lacking some indication of follow through, we highlight several examples where institutions indicated action. As the first example, when the U.S. Department of Justice and Education announced changes to Title IX legislation regarding transgender students' use of restrooms, the Chancellor at the University of Colorado Boulder released this statement:

First, I want to state unequivocally that we welcome, support and respect our transgender community and are here 
to engage you as a vital member of the CU Boulder community ... This announcement does not alter existing federal or Colorado law that provides discrimination protection for transgender people. This announcement does not change our Discrimination and Harassment Policy ... Sexual Misconduct Policy ... or our interpretation of either. We will continue to prohibit discrimination or harassment based on gender identity, gender expression and/or sexual orientation.

The Chancellor not only chose to espouse their support for transgender college students, they also reaffirmed the institution's policies that support this espoused value.

When the frequency of ICE raids increased in California, the Chancellor at UC Berkeley responded to the campus community, "We have no information or indication that ICE has plans to come to our campus. Yet, we want everyone to be fully prepared and informed." The Chancellor directed audiences to a document constructed by the University of California Office of the President that addressed some key questions and answers regarding the institution's ability to "protect the interests of our undocumented students and colleagues." The institution was also in the midst of preparing an action plan for ICE sweeps and shared several outlets through which communication regarding further developments would be shared.

The president of Illinois State University released a statement that included an indication of action in response to "potential changes in immigration laws." The statement first emphasized the institution's commitment to "providing a safe, secure and inclusive environment for all students and scholars, including international and undocumented students and scholars." Thus, we want to also highlight the connection here to the second theme-power in language. Specifically naming undocumented students and scholars within this community rendered these individuals visible and was a stronger demonstration of inclusion than a blanket statement such as "all members of our community"-which does not draw attention to power. However, the President also followed this statement with highlights from seven initiatives the institution and the President specifically had taken to demonstrate this commitment. Among these, the President noted that he signed a statement in support of the DACA program and 
Undocumented Immigrant Students; in addition, he supported "legislation entitled, Bar Removal of Individuals who Dream and Grow our Economy (BRIDGE).” At the institutional level, the President asserted:

SU policy protects all students, faculty and staff from discrimination and harassment based on their race, color, religion, sex, national origin, sexual orientation, order of protection, gender identity and expression, ancestry, age, marital status, disability, genetic information, unfavorable military discharge or status as a veteran in employment.

The President also added that the Illinois State University Police Department "does not ask about a person's immigration status unless it is specifically related to a criminal investigation being conducted by the department." In this regard, the President was not only espousing a particular belief, but also showing that they and the institution were willing to commit to actions that aligned with those beliefs.

\section{Discussion and Implications}

Institutions across the spectrum of higher education, but particularly public institutions, are at an impasse regarding free speech. Hate speech is relative. Hate shifts in scope and effect based on who perpetrates and who is victimized; studies of linguistic microaggression demonstrate that majority populations do not register the physiological ramifications of speech, which to them, are innocuous only because the majority population cannot recognize the implicit malice within microaggressions nor can they register the fact that good intent does not necessarily yield good outcomes. Put differently, hate may persist even if the perpetrator intends to be kind. Thus, establishing hate measures is fraught with potential miscommunications, implicit biases, and underestimated impacts (For more information on the physiological effects of microaggressions, see: Gartner \& Sterzing, 2016; Hollingsworth et al., 2017; Liu et al., 2019; Nadal, Griffin, Wong, Hamit, \& Rasmus, 2014; Nadal et al., 2011; Sue, 2010). Though it is hard to determine measures for hate, universities should be responsive to individuals who feel targeted by linguistic violence 
and treat their concerns as valid. Thus, vagueness in response statements, which often render hate as affecting all disenfranchised people equally or taking the same form for all disenfranchised groups, invalidates the feelings of the targeted group. For example, while racebased hate speech is generally viewed as socially unacceptable in collegiate settings, many institutions do not explicitly condemn queerphobic language in any form; many institutions even file for Title IX exemptions to keep from having to create antidiscrimination policies for the benefit of LGBTQ people (see Campus Pride for a list of all institutions receiving Title IX exemptions for "religious" reasons, as guise for LGBTQ exclusion). Thus, condemning a "white supremacist" message may not necessarily condemn queerphobic messages advocated by the same speaker.

Haberman (2000) draws our attention to the shortcomings of vagueness and the reluctance to be divisive, "Language is not an innocent reflection of how we think. The terms we use control our perceptions, shape our understanding, and lead us to particular proposals for improvement. We can see only as far as our language allows us to" (p. 203). When universities make blanket "anti-hate" statements, they often limit the optics of what forms of hate are at play within their contexts. Without "seeing" through language, campus communities cannot be proactive against discrete instances of hate that persist even after the offending speaker leaves. In addition, targeted students may feel invalidated by virtue of not being "seen" through language. Crenshaw (1991) illuminates how framing discussions around singular identity traits leads to failures in service to intersecting marginalized identities. Furthermore, trans_students (according to Simmons, 2017) are commonly invisible in campus communications, since trans students do not neatly fit into binaries, which otherwise might cover people along gender, sex, and sexuality lines.

These topics are important for evaluating the state/institutional nexus at the root of power dynamics regarding campus climate issues. Many institutions seemed reluctant to be proactive, possibly for fear of local retribution. A prime example included the University of Tennessee, which as discussed in the findings had funding for its Office of Inclusion and Diversity stripped by the state legislature in response to the University's proactive orientation toward inclusion. The University of Tennessee's example helps explain why many institutions 
may remain silent regarding campus climate issues, particularly those at odds with state political climates. Though the impulse to consider the risks in being unequivocally vocal is understandable, institutions must better understand the risks inherent in silence as well. Who is rewarded by silence? Who is punished by silence? Beyond the choice of speaking or not, institutions must be aware of the distinction of affect between being explicitly condemnatory and being vaguely resolved, which was exemplified by the findings of this study as well as by Cole and Harper (2017). Yet, when students' lives and wellbeing are at stake, can we afford to be abstract and vague? Abstract diversity is about as useful as silence. Not naming the issue points to the argument that when you discuss an issue you give more power to it. However, the same could be said of the reverse. How can we strive toward creating systemic change when we do not even name forms of discrimination as they emerge?

We argue that universities should certainly value a commitment to free speech and the free exchange of ideas, as guardians of academic/ intellectual freedom; however, vague, value-void statements that do not acknowledge the deeply felt physical and psychological ramifications that linguistic violence (manifest in hate speech) is akin to operating an inclusion program that is "color blind." To illustrate what we mean, we return to the closing lines of the Texas Tech University statement: "We foster and promote the freedom of expression, but condemn the use of hateful and derogatory language. As American citizens, we value our protections under the First Amendment, even when we do not support the content of a message." We note that no value judgments are explicitly made regarding hate speech. We also note that types of hate are unidentified, thus rendering "hate" a monolithic entity that affects all people equally. To that end, we suggest statements that more clearly place the institutions in alignment with the values of antibigotry speech. In addition, it is prudent to identify and condemn specific forms of bigotry represented by the speaker under scrutiny.

We acknowledge the difficulty that universities face with navigating linguistic violence, commitments to free speech, and visibility of different populations of disenfranchised students. We also recognize the impulse to be neutral, nondivisive. While we are not privy to the rationale for these statements, it is possible that DACA and Executive 
Order responses were more prevalent because those two issues would literally exclude students (by virtue of deportation or prevention of returning from homelands), whereas these other issues are not as clearly "exclusive." We also reason that these issues may be less risky politically speaking given that there is support for them within both political parties as opposed to other issues that may be greater political capital risks. There may be additional political implications for the prevalence of responses to the Executive Order and DACA given that the institutions used in this study are public institutions and are privy to federal, state, and local legislation and may have an 'obligation' to publicly respond to these issues. Nevertheless, universities can and should make value judgments against hate speech, and those values should be clear, even if still in the name of being "neutral." The University of Memphis navigates this kind of value-laden, though neutral, positioning well. The University of Memphis, while advocating free speech, still manages to illuminate how "freedom" makes room for hate under its umbrella. Pointing out this condition validates the experiences of historically disenfranchised populations who feel targeted for and by linguistic violence, since freedom includes the freedom to hate, which the university acknowledges as problematic (the university also positions itself more effectively as a reluctant protector of free speech through its stated plan to explore the boundary between free speech and disruptive speech).

Furthermore, within the findings, we discussed language's ability to be a powerful signal for institutional stance; however, we also addressed how diversity statements are but lip service if not paired with clear, robust strategies for change. The need for paired action aligns with findings from Davis and Harris (2016). As Davis and Harris (2016) asserted, institutions must be more intentional in working with the campus community to address climate issues and to ensure individuals with marginalized identities are recognized and feel a sense of belonging. Likewise the need for institutional action also aligns with Hoffman and Mitchell's (2016) finding that the labor for cultivating more inclusive environments often fell on the students. This may particularly be the case in instances where institutions choose to remain silent on climate issues or address them broadly without targeting the root of the issue and bringing about systemic change. We suggest the university make clear that is committed to providing 
additional resources to address similar linguistic modes of hate already extant on campus. Those resources could come in the form of alternative programming to counter the offending speaker's event, educational programming around implicit biases, or locating a speaker to provide a counternarrative to that of the message of hate so that the institution makes clear, through practice, their condemnation of hate speech. Many individual offices on campuses are already working toward these aims. Institutional leaders should recognize these efforts and communicate them in a unified way.

Although the focus of this study was on upper level administrative response to incidents challenging campus climates, these findings also have implications for other professional staff and faculty on campus. Similarly, these individuals may consider ways language used in their offices, official statements, and classroom rhetoric serve to lift up or further marginalize minoritized groups within the campus community. Though not every administrator or faculty member carries the same power or institutional influence as top level administrators, they often serve a more direct role in affirming students' identities and place within the institution (Blockett, 2017; Garcia, 2019; Tachine, Cabrera, \& Yellow Bird, 2017).

\section{Conclusion}

When events occur that could negatively affect campus climates, it is not enough for institutions to broadly espouse a commitment to diversity. If indeed institutions espouse commitments to equity and inclusion, institutions must go further in how they enact these espoused commitments and deconstruct ways that power and privilege play a role in these events. This study contributes to this conversation by deconstructing the ways that language itself is used as a form of power by institutional leaders, yet there were several notable limitations of this study that could be addressed in future research. First, our study focused on publicly available institutional response documents, which meant that institutions may have sent out responses to the campus community through immediate means of communication such as email listservs that we did not have access to, this may speak to the limited responses we located in response to local issues. Furthermore, 
our study relied on documents that were readily available to the public months or years after issues emerged. Some institutions may have archived these types of documents more frequently and in some cases, change in administration meant that previous responses were often deleted to make way for communication from newly hired personnel. Finally, we recognize that human error is always possible and that within the vast expanse of the Internet there may have been documents that we missed. In spite of these limitations, we still believe these data encompassed important findings and implications. Future studies can expand on this work by exploring the distinction between responses that are made publicly available versus those that are only sent through internal communication channels as well as institutional rationale for keeping some responses online while removing others. They may additionally more closely examine incidents that manifest at the local level and how those issues are addressed. Researchers can also further explore ways that institutional responses affect students' perceptions of campus climates, particularly for those with marginalized identities. Examining this dynamic from a student perspective would extend our understanding of ways these responses affect campus communities. Finally, studies should also center administrative perspectives on factors that constrain or support their release of statements on particular issues as well as ways they formulate the language within these statements. A better understanding of leaders' positioning and ability to release affirming responses could contribute to building more inclusive and responsive campuses.

\section{References}

Alvesson, M., \& Kärreman, D. (2011). Decolonizing discourse: Critical reflections on organizational discourse analysis. Human Relations, 64, 1121-1146. http:// dx.doi.org/10.1177/0018726711408629

Associated Press. (2017, August 9). Presidential election results: Donald J. Trump wins. New York Times. Retrieved from https://www.nytimes.com/elections/ results/president

Bakhtin, M. M. (1981). The dialogic imagination: Four essays (C. Emerson \& M. Holquist, Trans.). Austin, TX: University of Texas Press.

Blockett, R. A. (2017). 'I think it's very much placed on us': Black queer men laboring to forge community at a predominantly white and (hetero) cisnormative research institution. International Journal of Qualitative Studies in Education, 30, 800 - 816. http://dx.doi.org/10.1080/09518398.2017.1350296 
Blommaert, J., \& Bulcaen, C. (2000). Critical Discourse Analysis. Annual Review of Anthropology, 29, 447- 466. http://dx.doi.org/10.1146/annurev. anthro.29.1.447

Carspecken, P. F. (2012). Basic concepts in critical methodological theory: Action, structure and system within a communicative pragmatics framework. In S. R. Steinberg \& G. S. Cannella (Eds.), Critical qualitative research reader (pp. 4366). New York, NY: Peter Lang Publishing, Inc.

Chang, M. J. (2002). Preservation or transformation: Where's the real educational discourse on diversity? The Review of Higher Education, 25, 125-140. http:// dx.doi.org/10.1353/rhe.2002.0003

Cole, E. R., \& Harper, S. R. (2017). Race and rhetoric: An analysis of college presidents' statements on campus racial incidents. Journal of Diversity in Higher Education, 10, 318-333. http://dx.doi.org/10.1037/dheooooo44

Compton, J. (2018, February 11). Gay alumni raise \$300,ooo for defunded $U$. of Tennessee LGBTQ center. Knoxville, Tennessee: NBC News. Retrieved from https://www.nbcnews.com/feature/nbc-out/ gay-alumni-raise-300-ooo-defunded-u-tennessee-lgbtq-center-n846871

Crenshaw, K. (1991). Mapping the margins: Intersectionality, identity politics, and violence against women of color. Stanford Law Review, 43, 1241-1299.

Davis, C., \& Harris, J. C. (2016). But we didn't mean it like that: A Critical Race analysis of campus responses to racial incidents. Journal of Critical Scholarship on Higher Education and Student Affairs, 2(1), 25-30.

Denzin, N. K. (1978). The research act: A theoretical introduction to sociological methods (2nd ed.). New York, NY: McGraw-Hill.

Garcia, C. E. (2019). Belonging in a predominantly White institution: The role of membership in Latina/o sororities and fraternities. Journal of Diversity in Higher Education. Advance online publication. http://dx.doi.org/10.1037/ $\underline{\text { dheo000126 }}$

Gartner, R. E., \& Sterzing, P. R. (2016). Gender microaggressions as a gateway to sexual harassment and sexual assault: Expanding the conceptualization of youth sexual violence. Affilia, 31, 491-503. http://dx.doi. org/10.1177/0886109916654732

Glesne, C. (2010). Becoming qualitative researchers: An introduction (4th ed.). Boston, MA: Pearson.

Haberman, M. (200o, November). Urban schools: Day camps or custodial centers. Phi Delta Kappan, 82, 203-208.

Hardy, I., \& Woodcock, S. (2015). Inclusive education policies: Discourses of difference, diversity and deficit. International Journal of Inclusive Education, 19, 141-164. http://dx.doi.org/10.1080/13603116.2014.908965

Hoffman, G. D., \& Mitchell, T. D. (2016). Making diversity “everyone's business": A discourse analysis of institutional responses to student activism for equity and inclusion. Journal of Diversity in Higher Education, 9, 277-289. http://dx.doi. org/10.1037/dheo0o0o37 
Hollingsworth, D. W., Cole, A. B., O’Keefe, V. M., Tucker, R. P., Story, C. R., \& Wingate, L. R. (2017). Experiencing racial microaggressions influences suicide ideation through perceived burdensomeness in African Americans. Journal of Counseling Psychology, 64, 104-111. http://dx.doi.org/10.1037/couoooo177

Horton, M., \& Freire, P. (1990). We make the road by walking: Conversations on education and social change (B. Bell, J. Gaventa, \& J. Peters, Eds.). Philadelphia, PA: Temple University Press.

Hurtado, S., Alvarez, C. L., Guillermo-Wann, C., Cuellar, M., \& Arellano, L. (2012). A model for diverse learning environments: The scholarship on creating and assessing conditions for student success. In J. C. Smart \& M. B. Paulsen (Eds.), Higher education: Handbook of theory and research (pp. 41-122). New York, NY: Springer.

Hurtado, S., Milem, J., Clayton-Pedersen, A., \& Allen, W. (1998). Enhancing campus climates for racial/ethnic diversity: Educational policy and practice. The Review of Higher Education, 21, 279-302. http://dx.doi.org/10.1353/ rhe.1998.0003

Hurtado, S., Clayton-Pedersen, A., \& Allen, W., \& Milem, J. (1999). Enacting diverse learning environments: Improving the climate for racial/ethnic diversity in higher education (Vol. 26). Washington, DC: The George Washington University, Graduate School of Education and Human Development.

Hurtado, S., \& Ponjuan, L. (2005). Latino educational outcomes and the campus climate. Journal of Hispanic Higher Education, 4, 235-251. http://dx.doi. org/10.1177/1538192705276548

Indiana University Center for Postsecondary Research. (n.d.). The Carnegie Classification of Institutions of Higher Education, 2018 edition. Bloomington, IN: Author.

Iverson, S. V. (2007). Camouflaging power and privilege: A critical race analysis of university diversity policies. Educational Administration Quarterly, 43, 586611. http://dx.doi.org/10.1177/0013161X07307794

Iverson, S. V. (2012). Constructing outsiders: The discursive framing of access in university diversity policies. The Review of Higher Education, 35, 149-177. http://dx.doi.org/10.1353/rhe.2012.0013

Izadi, E. (2015, November 9). The incidents that led to the University of Missouri president's resignation. The Washington Post. Retrieved from https://www. washingtonpost.com/news/grade-point/wp/2015/11/og/the-incidentsthat-led-to-the-university-of-missouri-presidents-resignation/?utm term . fe 42 bef 8 cf7 74

Jaschik, S. (2015). Fear of new pronouns. Inside Higher Ed. Retrieved from https://www.insidehighered.com/news/2015/og/o8/u-tennessee-withdrawsguide-pronouns-preferred-some-transgender-people

Kincheloe, J. L., \& McLaren, P. (2002). Rethinking Critical Theory and qualitative research. In Y. Zou \& E. T. Trueba (Eds.), Ethnography and schools: Qualitative approaches to the study of education (pp. 88-138). Lanham, MD: Rowman \& Littlefield Publishers, Inc. 
Ladson-Billings, G. (1998). What is critical race theory and what is it doing in a nice field like education? International Journal of Qualitative Studies in Education: QSE, 11, 7-24. http://dx.doi.org/10.1080/095183998236863.

Lather, P. (1992). Critical frames in educational research: Feminist and poststructural perspectives. Theory into Practice, 31, 87-99. http://dx.doi. org/10.1080/00405849209543529

Lester, J. N., Lochmiller, C. R., \& Gabriel, R. (2016). Locating and applying Critical Discourse Analysis within educational policy: An introduction. Education Policy Analysis Archives, 24, 1-15.

Liu, W. M., Liu, R. Z., Garrison, Y. L., Kim, J. Y. C., Chan, L., Ho, Y. C. S., \& Yeung, C. W. (2019). Racial trauma, microaggressions, and becoming racially innocuous: The role of acculturation and White supremacist ideology. American Psychologist, 74, 143-155. http://dx.doi.org/10.1037/ampooo0368

Locks, A. M., Hurtado, S., Bowman, N. A., \& Oseguera, L. (2008). Extending notions of campus climate and diversity to students' transition to college. The Review of Higher Education, 31, 257-285. http://dx.doi.org/10.1353/ rhe.2008.0011

Maxwell, J. A. (2013). Qualitative research design: An interactive approach (3rd ed.). Thousand Oaks, CA: SAGE Publications, Inc.

Nadal, K. L., Griffin, K. E., Wong, Y., Hamit, S., \& Rasmus, M. (2014). The impact of racial microaggressions on mental health: Counseling implications for clients of color. Journal of Counseling \& Development, 92, 57-66. http://dx.doi. org/10.1002/j.1556-6676.2014.00130.x

Nadal, K. L., Issa, M. A., Leon, J., Meterko, V., Wideman, M., \& Wong, Y. (2011). Sexual orientation microaggressions: "Death by a thousand cuts" for lesbian, gay, and bisexual youth. Journal of LGBT Youth, 8, 234-259. http://dx.doi.org/1 0.1080/19361653.2011.584204

Nuñez, A.-M. (2009). Latino students' transition to college: A social and intercultural capital perspective. Harvard Educational Review, 79, 22-48. http://dx.doi.org/10.17763/haer.79.1.wh7164658k33w477

Saldaña, J. (2016). The coding manual for qualitative researchers (3rd ed.). Thousand Oaks, CA: SAGE Publications Inc.

Simmons, S. L. (2017). A thousand words are worth a picture: A snapshot of trans_ postsecondary educators in higher education. International Journal of Qualitative Studies in Education, 30, 266-284. http://dx.doi.org/10.1080/0951 8398.2016.1254303

Smith, D. (2009). Diversity's promise for higher education: Making it work. Baltimore, MD: Johns Hopkins University Press.

Strayhorn, T. L. (2012). College students' sense of belonging: A key to educational success for all students. New York, NY: Routledge. http://dx.doi. org/10.4324/9780203118924

Sue, D. W. (2010). Microaggressions, marginality, and oppression: An introduction. In D. W. Sue (Ed.), Microaggressions and marginality: Manifestation, dynamics, and impact (pp. 3-22). Hoboken, N. J.: Wiley. 
Tachine, A. R., Cabrera, N. L., \& Yellow Bird, E. (2017). Home away from home: Native American students' sense of belonging during their first year in college. The Journal of Higher Education, 88, 785-807. http://dx.doi.org/10.1080/0022 1546.2016 .1257322

Tamburin, A. (2018, May 2). Read Davenport's scathing termination letter from the UT president. Tennessee: Tennessean. Retrieved from https://www.tennessean. com/story/news/education/2018/05/02/beverly-davenport-termination-letteruniversity-tennessee-ut-president/574328002/

Tynes, B. M., Rose, C. A., \& Markoe, S. L. (2013). Extending campus life to the Internet: Social media, discrimination, and perceptions of racial climate. Journal of Diversity in Higher Education, 6, 102-114. http://dx.doi.org/10.1037/ a0033267

U. S. Census. (2015). Geography: Regions. Retrieved from https://www.census. gov/geo/reference/webatlas/regions.html

Wooffitt, R. (2005). Conversation Analysis and Discourse Analysis: A Comparative and Critical Introduction. Thousand Oaks, CA: SAGE. http://dx.doi. org/10.4135/9781849208765 